\title{
Patients' and family members' knowledge and views regarding diabetes mellitus and its treatment
}

\author{
HN Shilubane, MA Cur \\ Junior Lecturer , University of Venda \\ E Potgieter, D Litt et Phil \\ Associate Professor, University of South Africa
}

Correspondence address:

Prof E Potgieter

Department of Health Studies

POB Box 392,

UNISA, 0003

Tel : (012) 429-6545

Fax : (012) 429-6688

E-mail :potgie@unisa.ac.za

\begin{abstract}
Curationis 30(2): 58-65
Diabetes mellitus affects millions of people worldwide and its related complications continue to be of great concern. The outcome of diabetes depends mainly on the patient's self-management. Health care professionals therefore have a major responsibility to assist patients to acquire the essential knowledge, skills and attitudes towards self-management.

A quantitative survey was conducted to identify diabetic patients and family members' knowledge and views about diabetes and its treatment regimen. A convenient sample of 32 diabetics and 32 family members who attended two health care facilities in the Mopani district, Limpopo Province, was drawn. Two similar questionnaires, one for each group respectively, were completed by the subjects. The data was analysed by a computer programme, the Statistical Package for Social Sciences. Findings revealed that the diabetics and family members lack adequate knowledge on diabetes and its treatment. Recommendations regarding the required health education and assistance to be given to these patients and their family members were made.
\end{abstract}

\section{Opsomming}

Miljoene mense reg deur die wêreld ly aan Diabetes Mellitus en die verwante komplikasies bly 'n groot bron van kommer. Die gevolge van Diabetes hang grootliks af van die pasiënt se self-hantering van die toestand. Gesondheidsorg werkers het gevolglik 'n belangrike verantwoordelikheid tot ondersteuning van die pasiënte soclat". hulle die nodige kennis, vaardighede en houdings teenoor self-hantering kan verwerf. 'n Kwantitatiewe opname is gedoen om diabetiese pasiënte en familielede se kennis en beskouings van diabetes en die behandelings regime te identifiseer. 'n Gerieflikheidssteekproef van 32 diabete en 32 familielede wat twee gesondheidsorg fasiliteite in die Mopani distrik, Limpopo Provinsie besoek, is getrek. Twee soortgelyke vraelyste, vir elke groep onderskeidelik, is deur die deelnemers voltooi. Die data is deu' ' $n$ rekenaar program, die Statistiese Paket vir Sosiale Wetenskappe, geanaliseer. Die bevindings het getoon dat diabete en familielede nie oor voldoende kennis van diabetes en die behandeling daarvan beskik nie. Aanbevelings aangaande die vereiste gesondheidsvoorligting en ondersteuning wat aan hierdie pasiënte en hul familielede gegee behoort te word, is gemaak. 


\section{Introduction}

Diabetes mellitus is a significant public health concern in many countries because of the demand it places on health care services and the detrimental effect it has on the quality of life of those who have to live with the disease. Apart from being a leading cause of death, it causes major disabilities including blindness in adults, cardio-vascular degeneration, end-stage renal failure and non-traumatic amputations. As much as $80 \%$ of diabetics develop acute and long-term complications. Non-compliance by diabetics is a major prohlem faced by health care professionals. It has been reported that many patients on treatment drop out of care within a year and only a minority adhere to all the recommendations necessary for adequate control of diabetes (Bopape \& Peltzer, 2002:39; Sakamoto, Alberti \& Hotta, 1995:9). There is sufficient evidence that early detection. long-term normoglycaemia, improved delivery of care, and adequate health education for diabetes self-management, delay or attenuate the complications of diabetes (Black, Hawks \& Keene, 2001:1150; Huddle \& Kalk 2000:7).

The patients' records which are kept in the hospitals and clinics in the Limpopo Province in South Africa, show an annual increase in the number of diabetics This study was undertaken to establish diabetics' knowledge and view's about diabetes and its treatment in order to recommend ways of strengthening support to patients as there is a lack of information in the literature about diabetics' perspectives of the disease (McCord \& Bradenburg 1995:267). According to Nurymberg, Kreitler and Weissler (1996:26), successful management can be improved by a more patient centred approach, ie considering patients' knowledge, understanding. view's and goals as cognitive contents (beliefs) are expected to be related to compliance.

\section{Literature Review}

Although diabetes affects mostly adults from 25 years to 75 years, it also affects children as young as 3 years old (referring to Type I which is usually diagnosed before 30 years of age).The majority of diabetics however (90\% to 95\%), suffer from type II diabetes which results from an increase in the sensitivity of the pancreatic cells to insulin and a decrease in the amount of insulin produced, with onset of the disease after the age of 40 (Black, Hawks \& Keene, 2001:1149). Whittemore, Chase, Mandle and Roy (2002:18) reports that type II diabetes accounts for $80-90 \%$ of all cases in the United States of America and according to Ascott-Evans and Kinvig (2004:624), $40 \%$ of Americans over the age of 80 are diabetics. Molleutze and Levitt (2005:110,111,112,) cite a landmark study conducted in 1998 in South Africa which included 13,827 adults older than 15 vears, who reported a prevalence of diabetes in males and females of $2.4 \%$ and $3.7 \%$ respectively. However, a study done in the Western Cape by Levitt and co-workers (including 974 respondents) showed a prevalence of $10.8 \%$ of diabetes type II in the age group 30-65 years. According to these authors the global incidence of diabetes was 124 million in 1997, with 0.82 million in South Africa and it was estimated to double to 221 million in 2010. The prevalence in South Africa by 2010 was estimated to be $4.1 \%$ in adults (Molleutze \& Levitt 2005:113). The criteria for diagnosis of diabetes mellitus is a causal plasma glucose of $11.1 \mathrm{mmol} / \mathrm{L}$ or higher, or fasting plasma glucose of $7.0 \mathrm{mmol} / \mathrm{L}$ or higher (Friderichsen and Maunsbach 1997:56). The raised blood glucose levels characteristic of diabetes leads to abnormalities in the metabolism of carbohydrates, proteins and fats. The resulting hyperglycaemia may lead to acute metabolic complications and longterm cardio vascular and neuropathic degenerative changes. Acute complications include polyuria. polydipsia, hypo/hyperglycaemia and keto acidosis and long-term complications involve peripheral vascular disease, retinopathy, nephropathy, neuropathy, sexual disfunction, infections and skin disorders (Cleaver and Pallourios, 1994:175; Ganguli, 2003:6; Reuter, 2001:2; Smeltzer \& Bare, 1992:1022, 1057).

The desired outcomes of the medical management of diabetes include the restoration and maintenance of blood glucose levels to as near normal as possible by balancing diet, exercise and the use of oral hypoglycaemic agents or insulin. Diabetes can be controlled if patients adhere to a prescribed treatment regimen as there is sufficient proof that glucose control delays the atherosclerotic process and neuropathy (Campbell et al, 1997:55; Lewis and
Collier, 1992: 1304). The aim of the treatment of diabetes is to maintain blood glucose concentration between 4 to 12 mmol / L. Patients have to take responsibility for their own care and should therefore acquire the essential knowledge and skills to monitor urine and blood glucose levels, recognise and take preventive measures towards hypo/ hyperglycaemia and the complications of diabetes (Matwa, Chabeli, Muller and Levitt, 2003:12; Shilubane 2003:2).

Mason (1985) found in his study that diabetics were confused about the nature of their condition and lacked essential information pertaining to the management of their disease (Cleaver \& Pallourios 1994). Keller (1998) maintains that the diabetic patient's adjustment to the disorder depends largely on family. support, and that some negative patterns of interaction within the familv affect the adherence to the diabetic regimen, and can lead to lack of control and even to attacks of ketoacidosis, for example, alcoholism in the family. A study by Anderson, Donnelli and Dedrick (1990) reported misconceptions among patients about diabetes. Those patients who were on tablets or on a controlled diet, believed that their disease was less serious because they did not have to take insulin injections.

According to Baumann, Chang and Hoebeke (2002:192), the prevalence of diabetes is higher in minority groups and among those who are socio-economically disadvantaged, but the reason for that has not been given. Toljamo and Hentinen (2001:626) indicate the importance of social support for patients with chronic diseases as it promotes adherence to self-care, thereby achieving better metabolic control. They further indicate that emotional support might be a motivating factor in improving adherence to health recommendations. This is supported by the findings of Chen-Yen and Fensle (1996), Gowers, Jones, Kiana, North and Price (1995), Keller in Cleaver and Pallowios (1994) and Ruth (1999), that the patient's type of support system does have an influence on his/her adherence to the diabetic regimen. Individuals are more likely to adhere to their diabetic health regimen if the quality of their interaction and relationship with their health providers is good and if the individuals have good social support. Patients whose families are supportive take their medication 
correctly, follow a diabetic diet such as low' fat, high carbohydrate and fruit, and participate in various exercises such as walking, running, rugby and swimming (Gowers et al 1995).

Savoca and Miller (2001:334) indicate that previous research showed that people with diabetes found the most difficult component of their self-care regimen to be adhering to a healthy diet. People with diabetes were reported to be more resistant to dietary change when compared to people with other chronic diseases. Fukunishi and Akimoto 11997:1367) and Whittemore et al (2002:23) affirm this reporting that diabetics seem to fail in keeping to an appropriate diet for various reasons.

According to Bain $(2001: 4,15)$ diabetes as a self-managed condition which requires from patients relevant knowledge, skills and attitudes for the successful management of diabetes. Councelling and health education should include information on regular home monitoring of blood and urine glucose levels, weight control, dietary restrictions, regular exercise, foot care, eye care and social contact with local interest groups. They must be reassured about the continuity of care and the value of compliance with the treatment regimen, and the family should be involved in the treatment regimen to offer support and encouragement. This is affirmed by Kyngas and Rissanen (2001:771) who indicate that the predictor of good compliance includes support form nurses, Physicians, parents and friends. Rasmussen, Wellard \& Nankervis (2002:629) state that if patients are encouraged to actively participate in decisions, they ultimately achieve higher levels of compliance.

According to Westaway, Rheeder, Van Zyl and Seager (2002:69), various studies have indicated the importance of clear communication and information, courtesy, consideration, partnership building, more social conversation, more immediate and positive non-verbal behaviour and interpersonal competence when dealing with diabetic patients. The length of consultation, frequency of contact, technical competence and service availability were identified as factors which increase patient satisfaction.

\section{Research objectives}

The objectives of this study were to: determine diabetics' and family members' knowledge and views about diabetes mellitus and its treatment

make recommendations with regard to strengthening support to diabetics and their family members.

\section{Research design}

A quantitative, descriptive survey design was used to assess the knowledge of patients and family members regarding diabetes mellitus and its treatment. Surveys are designed to study a wide range of phenomena and provide information from populations regarding the prevalence, distribution and interrelations between variables (Polit \& Hungler 1999:200-201)

\section{Research setting}

The study was conducted at Nkhensani Hospital and Givani Health Centre which fall under the Lowveld Region. Mopani District in the Limpopo Province (RSA) The hospital has an average bed occupancy of 253. It caters for the health needs of people who are referred to it from 20 clinics. The majority of the clients are black. Giyani Health Centre has a bed occupancy of 10 and is $2.5 \mathrm{~km}$ south-east of Nkhensani Hospital. It refers its clients to Nkhensani.

\section{Population and Sampling procedures}

The study population consisted of all the diabetic patients and their family members in the Mopani District that falls under the Lowveld region in the Limpopo Province, South Africa. The respondents were diabetic patients re-admitted to the hospital due to their condition, and those that visited the Satelite Health Centre together with their family members including spouse, parents, older children and in-laws. Hospital records were used to trace those in the community, as they provided their residential addresses. $A$ convenient sample of 64 respondents was chosen using snowball sampling, 32 were diabetic patients and 32 family members. The diabetics and family members were not related. Convenient sampling was done during visits to the hospital, satellite clinic, and in the community over a six month period.

The respondents were selected to meet specific criteria. Inclusion criteria for the diabetic patients were: being diagnosed with diabetes for at least 5 years, mentally sound to give informed consent, willing to participate, 18 years or older, of either gender or any race. Inclusion criteria for the family members were: living with a diabetic patient, mentally sound, willing to participate, 18 years or older, of either gender or any race.

\section{Method of data collection}

Self-report questionnaires were used to collect data on the respondents' knowledge of diabetes mellitus and its treatment regimen. The content of the questionnaires was based on a literature review and consisted of a section $A$ (demographic data such as age, gender, level of education and income) and a section $B$ aimed at determining the knowledge and views of diabetics and family members (including items on the diabetic diet, treatment regimen, exercise, foot care, emotional and other problems experienced). Closed ended questions were mostly asked with three options for responding: agree, unsure or disagree. There were a few open ended questions. Only two additional questions were added for the diabetic patients. questionnaire which related to changes in body functions and reasons therefore - the other questions were the same for both questionnaires.

The researcher personally delivered two questionnaires, one to diabetic patients and the other to family members of diabetics. The respondents were found in the wards, during visiting times, the satellite clinic and at their homes. Questionnaires were in both English and Xitsonga, to enable those who did not understand English to answer in Xitsonga. Those respondents who could not read were assisted by the researcher who remained with the them while they were completing the questionnaires to explain questions that were not clear.

\section{Reliability and validity} Reliability

The two questionnaires which were completed by the diabetic patients and family members respectively, revealed consistency in responses. According to Polit and Hungler (1999:411), reliability refers to the consistency with which an instrument measures the attribute it is designed to measure. Data collector bias was minimised by the researcher being the only one to administer the questionnaires, exhibiting similar personal attributes to all respondents, 
e.g., friendliness, support and clarification of questions when needed, ensuring privacy, confidentiality and general physical comfort. All questionnaires were completed in the presence of the researcher.

The questionnaires were pre-tested on six respondents meeting the set criteria at the Givani Health Centre, three diabetic patients and three family members. All of them could answer the questions and no clarifications or changes were necessary. The questionnaires were translated into Xitsonga by the researcher (who's home language is Xitsonga) and discussed with two respondents (who could speak both English and Xitsonga) during the pre-test to ensure reliability.

\section{Validity}

Content validity of the instruments was achieved by including a variety of questions based on information gathered during the literature review to ensure that these were representative of what patients should know about diabetes mellitus and its treatment. The questions were formulated in simple language for clarity and ease of understanding.

For validation, the questionnaires were submitted to another researcher and statistician. As a result more questions were added to ensure higher representativeness. Rephrasing of some questions was done to clarify the questions and appropriate alternative response choices for the closed-ended questions were indicated for provision of meaningful data analysis (Burns \& Grové 1997:373).

\section{Ethical considerations}

Written permission to conduct the study was obtained from the Assistant Director of Nkhensani Hospital and the Research Committee of the Department of Health and Welfare of Limpopo's Provincial Office. The Department of Health Studies' Research Committee at Unisa, approved the research instruments. Verbal permission was obtained from the persons in charge of the Adult Medical and Surgical Wards (Nkhensani Hospital) and Givani Health Centre. The respondents' consent was obtained before they completed the questionnaires. They were informed of their rights to voluntary consent or decline to participate, and to withdraw participation at any time without penalty. Anonymity was ensured by not disclosing the respondent's name on the questionnaire and research reports and detaching the written consent from the questionnaire. Confidentiality was maintained by keeping the collected data confidential and by not revealing the respondents' identities during reporting or publishing of the study. The researcher maintained scientific honesty by recording truthfully the answers of those subjects who could not read or write. Manipulation of data could not be done as an independent statistician entered the data from the questionnaires into the SPSS computer programme.

\section{Data analysis}

Data analysis was done by a computer software program called SPSS (Statistical Package for Social Sciences). For the closed-ended questions descriptive statistics were used whereas data from the few open-ended questions were analysed by the researcher through content analysis.

\section{Results and Discussion}

The results are discussed according to the demographic data, followed by a discussion of the knowledge and views of diabetes as portrayed by the responses of the diabetics and their family members. The discussion is supported by relevant literature. Table 1 provides a summary of the main findings.

\section{Demographic data}

The majority of the respondents included in this study were adults, $93 \%$ of the patients and $87.5 \%$ of the family members. They are literate and educated and the majority receive and income, only $21.9 \%$ receive no income. All respondents live within five kilometres of the available health services. They therefore have the ability and means to adhere to the diabetes mellitus treatment regimen.

\section{Knowledge of patients and family members about diabetes mellitus}

Table 1 portray the findings obtained from both groups.

The majority of the subjects could not explain the term diabetes mellitus well and $62.5 \%$ patients as well as $62.5 \%$ family members indicated that it can be cured. There are still a few misconceptions that treatment of the disease can be done through withdrawal of sugar and that once the blood sugar is normal, the treatment can be discontinued. Many patients (59.4\%) as well as family members' $(84.4 \%)$ responses indicated they have never attended organised programmes for diabetic patients, which actually serve as support and source of information. According to Chen-Yen Fenske (1996:468) and Gowers et al (1995:995), adherence to the diabetic regimen is influenced by the type of support system the patient has.

A high percentage of patients (43.8\%) and family members (50\%) are not aware of the warning signs of hypoglycaemia and will therefore not know how to behave pro-actively to prevent the patient falling into a hypoglycaemic coma.

The majority of the patients (75\%) do not test their urine, which was confirmed by $59.4 \%$ family members, and 56.3\% patients indicated they never visit the clinic for glucose monitoring, confirmed by $87.5 \%$ family members. This is alarming as the majority of the subjects in this study are on treatment including tablets and insulin which necessitate proper control. Regular attendance of diabetic clinics forms part of the management of diabetes. These clinics exist to review treatment and control of blood glucose, to screen for early detection of complications like retinopathy and neuropathy, and for the provision of ongoing health education and patient support. Coates (1994:265) found that clinic attendance is associated with reduced diabetic morbidity. Patients who were attending the clinic infrequently had poor glycaemic control in comparison to those who attended regularly. Patients and family members should be instructed on how to do blood glucose monitoring as it is preferable to urine glucose monitoring because of accuracy. It should be done daily and the data used to self-adjust the diet, exercise and medication. Blood glucose monitoring assists in identifying and treating hyper-and hypoglycaemia (Lewis et al, 1996:1455; The Primary Health Care Package for South Africa 2002).

Almost half of the patients (46.9\%) do not carry snacks with them, which is essential to prevent hypoglycaemia. This, together with the high percentage of patients and family members who do not know the signs of hypoglycaemia, is cause for concern. Almost half of the patients $(46.9 \%)$ and family members (46.9\%) have not been counselled on nutrition and therefore the correct diet 
Table 1: Findings on knowledge and views of patients and family members about diabetes mellitus

\begin{tabular}{|c|c|c|c|c|c|c|}
\hline \multirow[b]{2}{*}{ Knowledge about diabetes mellitus } & \multicolumn{3}{|c|}{ Patients } & \multicolumn{3}{|c|}{ Family members } \\
\hline & Agree & Disagree & Unsure & Agree & Disagree & Unsure \\
\hline Diabetes mellitus can be cured & $20(62.5 \%)$ & 12 & 0 & $20(62.5 \%)$ & 12 & 0 \\
\hline Withdrawing sugar treats diabetes & 7 & 20 & 5 & 7 & 22 & 3 \\
\hline Diabetic programme attendance & 13 & $19(59.4 \%)$ & 3 & 2 & $27(84.4 \%)$ & 3 \\
\hline Warning signs of hypoglycaemia & 18 & 0 & $14(43.8 \%)$ & 16 & 0 & $16(50 \%)$ \\
\hline Urine testing & 8 & $24(75 \%)$ & 0 & 13 & $19(59.4 \%)$ & 0 \\
\hline Visit the clinic for glucose monitoring & 14 & $18(56.3 \%)$ & 0 & 4 & $28(87.5 \%)$ & 0 \\
\hline $\begin{array}{l}\text { Patient carry snacks to prevent } \\
\text { hypoglacaemia }\end{array}$ & 17 & $15(46.9 \%)$ & 2 & 18 & $14(44.8 \%)$ & 0 \\
\hline Going for nutrition counselling & 17 & $15(46.9 \%)$ & 0 & 17 & $15(46.9 \% 0$ & 0 \\
\hline Exercise daily & $22(65.6 \%)$ & 10 & 0 & $15(46.9 \%)$ & 11 & 6 \\
\hline Need for sexual educational programmes & $29(90.8 \%)$ & 1 & 2 & & & \\
\hline Feet are examined daily & $19(59.4 \%)$ & 13 & 0 & $30(93.7 \%)$ & 2 & 0 \\
\hline Visit the podiatrist & 2 & $30(93.8 \%)$ & 0 & 5 & $27(84.4 \%)$ & 0 \\
\hline Visit the ophthalmologist & 16 & $16(50 \%)$ & 0 & 10 & $22(68.8 \%)$ & 0 \\
\hline \multicolumn{7}{|l|}{$\begin{array}{l}\text { Views of patients and family members on } \\
\text { diabetes mellitus }\end{array}$} \\
\hline $\begin{array}{l}\text { Traditional healers know better how to treat } \\
\text { diabetes }\end{array}$ & 2 & $19(59.4 \%)$ & 11 & 2 & $20(62.5 \%)$ & 10 \\
\hline Visit traditional healers & $10(31.2 \%)$ & 22 & 0 & $7(21.9 \%)$ & 25 & 0 \\
\hline $\begin{array}{l}\text { A person with diabetes is a burden to the } \\
\text { family, }\end{array}$ & $11(34.4 \%)$ & 17 & 4 & $6(18.8 \%)$ & 21 & 5 \\
\hline $\begin{array}{l}\text { Lack of money interferes with management } \\
\text { of diabetes }\end{array}$ & $24(75 \%)$ & 0 & 8 & $23(71.9 \%)$ & 8 & 1 \\
\hline $\begin{array}{l}\text { People with diabetes should loose their jobs } \\
\text { and status }\end{array}$ & 0 & $30(93.8 \%)$ & 2 & 1 & $29(90.6 \%)$ & 2 \\
\hline
\end{tabular}

for diabetic patients. According to Savoca and Miller (2001:225) most diabetics fail to adhere to a healthy diet which might be due to failure to attend nutrition counselling offered by a dietician.

More than half of the patients $(65.6 \%)$ indicated that they exercise every day (most of them walk for exercise and this was confirmed by $46.9 \%$ of the family members), but there is a percentage who do not walk at all for exercise. Liska, May and David (1997:99) found in their study that diabetics are less likely to follow medical recommendations particularly with regard to diet and exercise. Exercise should be part of the daily activities of diabetics as it lowers blood glucose through increasing the uptake of glucose by the body muscles, improve insulin utilisation, and reduces cardio vascular risk factors.

With regard to sexual problems, $50 \%$ of the patients affirmed experiencing problems and $90.6 \%$ of them indicated a need for sexual educational programmes. Diabetics often suffer from some degree of neuropathy (peripheral, autonomic and spinal nerves can be affected) and autonomic neuropathy includes ie urinary and sexual disfunction for 
diabetic patients. According to Savoca and Miller (2001:225) most diabetics fail to adhere to a healthy' diet which might be due to failure to attend nutrition counselling offered $b v$ a dietician.

More than half of the patients $(65.6 \%)$ indicated that they exercise every day (most of them walk for exercise and this was confirmed by $46.9 \%$ of the family members), but there is a percentage who do not walk at all for exercise. Liska, May' and David (1997:99) found in their study that diabetics are less likely to follow medical recommendations particularly with regard to diet and exercise. Exercise should be part of the daily activities of diabetics as it lowers blood glucose through increasing the uptake of glucose by the body muscles, improve insulin utilisation and reduces cardio vascular risk factors.

With regard to sexual problems, $50 \%$ of the patients affirmed experiencing problems and $90.6 \%$ of them indicated a need for sexual educational programmes. Diabetics often suffer from some degree of neuropathy (peripheral, autonomic and spinal nerves can be affected) and autonomic neuropathy includes ie urinarv and sexual disfunction.. Elevated blood glucose levels over a period of years have been indicated in the etiology of neuropathy (Naudé 2003:2). Neuropathy can be prevented or delayed through blood glucose control (Campbell et al 1997:55; The Viagra Boom 1998:20).

More than half of the patients (59.4\%) and $93.7 \%$ of family members affirmed that diabetics examine their feet and the greater majority of patients (93.8\%) indicated they never visit the podiatrist - this was confirmed by $84.4 \%$ of the family members. According to Sanders (1995:10) and New fast Acting Insulin (1997:50) diabetics should examine their feet for redness, blisters, calluses and ulceration daily and should visit a podiatrist even' six weeks. Reuter (2001:1) reported that most cases of gangrene in diabetics occur as a result of severe arterial occlusions in the lower extremities. Several studies showed that the incidence of lower limb amputations in diabetics could be reduced when a foot care teaching programme for diabetics was offered (Matwa et al (2003:12). The examination of diabetics' feet by health care providers during clinic visits is essential as peripheral vascular disease causes arterial occlusion in the lower extremities with the result that wounds heal poorly and foot injuries easily occur because of the loss of sensation due to neuropathy. Diahetic foot ulcers are the most common foot injuries that may lead to amputation. Self-management of diabetes includes proper foot care and therefore careful instructions to patients (Naudé, 2003:2)

Only $50 \%$ of the patients indicated that they visit an ophthalmologist, this finding being affirmed by $68.8 \%$ of the family members. Retinopathy is one of the longterm complications of diabetes and according to Campbell et al (1997:69) and Coates (1994:268), regular monitoring of diabetics 'vision is essential for they' will not benefit from treatment once they already experience loss of vision.

\section{Views of patients and family members on diabetes mellitus}

More than half of the patients $(59.4 \%)$, and $62.5 \%$ family' members do not believe that traditional healers know how' to cure diabetes, and only $31.2 \%$ of patients and $21.9 \%$ of family members indicated that patients had visit traditional healers. This is an interesting finding for this group as according to Setswe (1999:56), up to 80\% of African diabetics in South Africa consult a traditional healer before going to a primary health care practitioner.

Only $34.4 \%$ patients and $18.8 \%$ family members regard diabetics as a burden to the family and gave the reasons as because of the need for care and the special diet that has to be followed. The patients experience living with diabetes as stressful because of the medication they have to take, the inability' to satisfy' their partners' sexual needs and the special diet they have to follow. Although the majority of family members do not regard the patients as a burden, they' do regard living with diabetics as difficult because of the dietary restrictions and the need for money to attend the health clinic on a regular basis. Ruth (1999:420) found that diabetics who are supported by family take their medication as prescribed, follow the correct diet and exercise regularly:

The majority of patients (75\%) and family members (71.9\%) experience lack of money as an interference with diabetes control because of problems of getting to the health sevices and purchasing the correct food. Bauman et al (2002:191) reported the morbidity from diabetes to be more severe in low income groups and less than half of the type II diabetics in their study, achieved a blood glucose level of less than $7 \mathrm{mmol} / \mathrm{L}$. Both the patients (93.8\%) and family members (90.6\%), acknowledged that patients should stay in their jobs because of the financial benefit which enables them to adhere to the treatment regimen.

Patients indicated that they experienced feelings of denial, hurt, shock, uncertainty and depression when first diagnosed with diabetes mellitus. Family members confirmed this. More than half of the patients in the sample reported they fear injury, blindness, divorce and death. Bain (2001:3) found in his study that $21-24 \%$ of diabetics had one episode of depression before being diagnosed with diabetes and patients who are depressed are less likely to control their blood glucose levels. Toljamo and Hentinen (2001:619) indicate that social and specifically emotional support, are important to patients suffering from chronic diseases and is a motivating factor in adhering to health recommendations and self-care.

\section{Limitations}

Findings can only be generalised to diabetic patients in the Mopani district in the Limpopo Province, South Africa, who visit the Nkhensani Hospital and Satelite Health Centre. This was the major limitation. Other limitations include the sample size and that only adult diabetics who have been diagnosed with diabetes for at least five years, were involved in the study.

\section{Conclusion and Recommendations}

It is evident from this studv that diabetics and family' members caring for diabetics do not have adequate knowledge of the disease itself, its treatment, how to avoid complications, and how to maintain a healthy lifestyle. Proper self-management of diabetes could be improved by enhancing diabetics' knowledge and understanding of the disease and its treatment. The importance of being supported by their family members cannot be over emphasised. Diabetics and their family members should therefore be well informed and receive ongoing support from health professionals.

The following recommendations are proposed:

- Health professionals should 
give proper health education to patients and family members on diabetes mellitus and the required treatment regimen. It should be explained that diabetes is an incurable chronic disease which requires lifelong adherence to the treatment regimen to control the disease, thereby preventing short term and long term complications. Explaining diabetes mellitus and its causes to the patients might help them to understand and accept their condition. It must be explained to patients that the aim of the treatment is to maintain a normal blood sugar. level, and that once treatment is discontinued, complications may set in.

Informing patients and family members about organised programmes for diabetics in their area and encouragement to participate in these on a regular basis, could serve as a basis of support.

- $\quad$ Patients and family members must be coached on the warning signs and symptoms of hypoglycaemia and hyperglycaemia and how to act pro-actively in such a situation to prevent hypol hyperglycaemic coma.

- Health professionals should teach patients how to test their urine and blood for glucose levels. It must be emphasised that blood glucose monitoring is preferable to urine glucose monitoring because it provides more accurate readings. The importance of regular visits to the clinic for glucose monitoring must be emphasised and records of patient appointments should be kept. should be given to patients as well as family members. Health professionals should explain why smaller meals should be taken more often and snacks taken in between meals.

Patients must be advised on the essential food for diabetics as well as forbidden food. If available, health professionals should refer patients to a dietician

The availability of health professionals who listen to patients' fears and uncertainties is extremely important for maintaining psychological wellness. Many of the fears experienced by diabetics can be alleviated by providing them with more information on diabetes and the prevention of complications. Visits to spiritual healers can be encouraged but it must be emphasised that regular visits to the health clinic are essential. Patients must be observed for signs of depression and referred to a psychologist or psychiatrist if necessary.

- Health professionals must advise patients and family members that daily exercise is essential as it increases the effect of insulin and therefore the uptake of glucose by the body cells. It helps with losing weight, strengthens the body and creates a feeling of well being and relaxation. Exercise can be in the form of walking, gardening, swimming, athletics, aerobics, plaving soccer and doing domestic work.

Educational programmes on sexual problems could be organised at health clinics where physicians as well as nurses can be involved in providing information to patients.

- $\quad$ Appropriate advice to patients on foot care is essential. The wearing of comfortable leather shoes, proper cleaning of feet, daily inspection of feet for colour changes and cracks as well as 6 weekly visits to the podiatrist at the health clinic for proper foot and nail care, must be emphasised and appointments must be made for patients.

- It is suggested that diabetics visit an ophthalmologist annually for eye tests and even for a routine glaucoma evaluation every 2-5 years. $B y$ making these appointments for them health professionals can ensure better control.

Family members of diabetics should ideally be counselled by health professionals on the importance of supporting the patients psychologically. because of the negative feelings experienced when diagnosed and having to live with an incurable disease. They must be made aware of the supportive role they play by supervising patients with regard to their diet, the taking of medication and regular visits to the clinic for glucose monitoring.

\section{References}

ANDERSON, RM; DONELLI, MB \& DEDRICK, RF 1990: Measuring attitudes of patients towards Diabetes and its treatment. Patient Education and Counseling. 16:231-245.

ASCOTT-EVANS, BH \& KINVIG, T 2004: Endocrine disorders in the elderly. CME. 22(11): 623-628.

BAIN, K 2001: depression and diabetes. Health and Hygiene. 12(11):3-15

BAUMANN, LC; CHANG, M \& HOEBEKE, R 2002: Clinical outcomes for low-income adults with hypertension and diabetes. Nursing Research. 51(3):190-195.

BLACK, JM; HAWKS, JH \& KEENE, AM 2001: Medical-surgical Nursing. Vol $1,6^{\text {th }}$ edition. Philadelphia: WB Saunders.

BLACK, JM \& MATASSARINJACOBS, E 1993: Luckmann and Sorensen's medical-surgical nursing: a psychophysiologic approach. $4^{\text {th }}$ edition. Philadephia: WB Saunders.

BOPAPE, MW \& PELTZER, K 2002: Health beliefs and stress among noninsulin dependent diabetes out-patients in a rural teaching hospital in South Africa. Health SA Gesondheid. 7(4):38-46.

BURNS, N \& GROVE, S 1997: The practice of nursing research conduct, critique and utilization. $3^{\text {rd }}$ edition. Philadelphia: WB Saunders.

CAMPBELL, RK; PEARSON, TL; RATNER, RE \& WYSHAM, CH 1997: Managing diabetes and its complications: a guide for health care providers. Washington: Lifescan.

CHEN-YEN, W \& FENSKE, MM 1996: 
Self-care of adults with non-insulin dependent diabetes mellitus: influence of family and friends. The Diabetes Educator: 22(5):465-469.

CLEAVER, G\& PALLOURIOS, H 1994:

Diabetes mellitus: experiencing a chronic illness. South African Journal of Psvcholog: 24(4):175-183.

COATES, VE 1994: Monitoring diabetic control. Journal of Clinical Nursing. B):263-269.

DIABETES EDUCATION 2001: $\underline{\text { Health }}$ and Hy giene. $12(11): 4,15$

FRIDERICHSEN, B, \& MAUNSBACH, M 1997: Glucosuric tests should be employed in population screenings for NIDDM. Journal of Public Health Medicine. 19(1):55-60

FUKUNISHI, I \& AKIMOTO, M 1997: Development of the eating attitude inventory for diabetes mellitus. Journal of the Roval Anthropological Institute. 3(2):1363-1371.

GANGULI,P 2003: Call for new diabetic nephropathy check. Nursing Times. 99(26):6.

GOWERS, SG; JONES, JC; KIANA, S; NORTH, CD \& PRICE, DA 1995: Familv functioning: a correlate of diabetic control. Journal of Child Psvchologv \& Psvchiatn: 993-1001.

HUDDLE, KRL \& KALK, WJ (eds). 2000: Practical diabetes management. $3^{\text {rd }}$ edition. Johannesburg: Wits Diabetes Group.

KYNGAS, H \& RISSANEN, M 2002: Support as a crucial predictor of good compliance of adolescents with a chronic disease. Journal of clinical nursing. (10):767-774.

LEWIS, SM \& COLLIER, IC 1992: Medical-surgical nursing: assessment and management of clinical problems. $3^{\text {th }}$ edition. St Louis: Mosby.

LEWIS, SM; COLLIER, IC \& HEITKEMPER, MM 1996: Medicalsurgical nursing: assessment and management of clinical problems. $4^{\text {th }}$ edition. St Louis: Mosby.

LISKA, BA; MAY, LW \& DAVID, C 1997: Medical self-care compliance with recommended treatment regimens among chronically ill middle-aged and elderly persons. Research in the Sociology-ofhealth-care. 14:99-117.

MATWA, P; CHABELI, MM; MULLER, M \& LEVITT, NS 2003: Experiences and guidelines for foot care practices of patients with diabetes mellitus. Curationis $26(l): 11-21$

MOLLEUTZE, WF \& LEVITT, N 2005 : Diabetes mellitus and impaired glucose tolerance in South Africa. [Online] http:/ /www.mrc.ac.za/bod.htm [Accessed: 4 October 2006]

NAUDÉ, L 2003: Diabetic ulcers. Health and Hvgiene. $14(11): 2,4,8,10$.

NEW FAST-ACTING INSULIN 1997: Diabetes Focus. 48-49.

POLIT, DF \& HUNGLER, BP 1999: Essentials of nursing research: methods, appraisal and utilization. $4^{\text {th }}$ edition. Philadelphia: JB Lippincott.

RASMUSSEN, B; WELLARD, S \& NANKERVIS, A 2002: Consumer issues in navigating health care services for type I diabetes. Journal of clinical nursing. (10): 628-634.

REUTER, H 2001: Feeling tired? ww'w. Health 24.co.za (access date 2003.08.28).

ROYLE, JR \& WALSH, M 1992: Watson's medical-surgical nursing and related physiology. 4th edition. London. Bailliere Tindall.

RUTH, LO 1999: Correlates of expected success at adherence to health regimen of people with IDDM. Journal of Advanced Nursing. 30(2):418-425.

SAKAMOTO, N; ALBERTI, KGMM \& HOTTA, N 1995: Recent trends in management of diabetes mellitus. Armsterdam: Biomedical Division.

SANDERS, FN 1995: $3 l^{s t}$ Annual Congress. Society for Endocrinology, Metabolism and Diabetes of South Africa. Pinelands: Masa Publication.

SAVOCA, M \& MILLER, C 2001: Food selection and eating patterns: themes found among people with type 2 diabetes mellitus. Journal of Nutrition Education. 33(4):224-338.
SETSWE, G 1999: The role of traditional healers and primany health care in South Africa. Health South Africa. 4(2):56-60.

SHILUBANE, HS 2003: Knowledge of patients and family members regarding diabetes mellitus and its treatment. MA Dissertation. Pretoria: UNISA.

SMELTZER, SG \& BARE, BG 1992: Brunner and Suddath's textbook of medical-surgical nursing. $7^{\text {th }}$ edition. Philadelphia: JB Lippincott.

THE PRIMARY HEALTH CARE PACKAGE FOR SOUTH AFRICA 2001: $A$ set of norms and standards. Pretoria: Department of Health.

THE VIAGRA BOOM 1998: Diabetes focus. 22-24.

TOI JAMO M \& HENTINEN, M 2001: Adherence to self-care and social support. Journal of Clinical Nursing. (10):618-627.

TRAVIS, T 1997: Patient perceptions of factors that affect adherence to dietary regimens for diabetes mellitus. The Diabetes Educator: 23(2): 152-156.

WESTAWAY,MS; RHEEDER, P; VAN ZYL, DG \& SEAGER, JR 2002: Development and testing of a 25-item patient satisfaction scale for black South African diabetic outpatients. Curationis. 25(3):68-75.

WHITTEMORE, R, CHASE, SK, MANDLE, CL \& ROY,SC 2002: Lifestyle change in type II diabetes. Nursing Research. 51(1):18-25 